Jurnal Ilmu-Ilmu Peternakan 26 (2) : 1-7

ISSN : 0852-3681

E-ISSN : 2443-0765

CFakultas Peternakan UB, http://jiip.ub.ac.id/

\title{
Sintesis protein mikroba dan aktivitas selulolitik akibat penambahan level zeolit sumber nitrogen slow release pada glukosa murni secara in vitro
}

\author{
Al Qori’ah, Surono, Sutrisno \\ Fakultas Peternakan dan Pertanian Universitas Diponegoro \\ Kompl. drh. R. Soejono Koesoemowardojo-Tembalang, Semarang Kode Pos 50275 \\ alqoriah.me@gmail.com
}

\begin{abstract}
This research aimed to determine the effect of the level of zeolites as slow release nitrogen in pure glucose on microbial protein synthesis and cellulolytic activity. The material used were zeolite of clinoptilolite type with size 40-60 mesh, urea, pure glucose, cow's rumen fluid from RPH Ungaran. The research used completely randomized design (CRD) with 5 treatments and 4 replications. The treatments were T1, T2, T3, T4 and T5 = pure glucose + additional level 2\%, 4\%, 6\%, 8\% and 10\% of zeolite slow release respectively. Variables observed were microbial protein synthesis and cellulolytic activity. The results showed that the treatment significantly $(\mathrm{P}<0.05)$ increased microbial protein synthesis and cellulolytic activity. Results of protein synthesis from higher to lower number were T2 $(59.50 \mathrm{mg} / \mathrm{ml})$, T3 $(55.58 \mathrm{mg} / \mathrm{ml}), \mathrm{T} 4(47.55$ $\mathrm{mg} / \mathrm{ml})$, T5 $(42.82 \mathrm{mg} / \mathrm{ml})$ and $\mathrm{T} 1(31.68 \mathrm{mg} / \mathrm{ml})$ respectively. Results of cellulolytic activity from higher to lower number were T5 (3.55 mol ml$\left.{ }^{-1} \mathrm{~min}^{-1}\right)$, T4 $\left(2.36 \mathrm{~mol} \mathrm{ml}^{-1}\right.$ $\mathrm{min}^{-1}$ ), T2 (2.23 mol ml$\left.{ }^{-1} \mathrm{~min}^{-1}\right)$, T3 (2.16 mol ml${ }^{-1} \mathrm{~min}^{-1}$ ) and T1 (2.09 $\mathrm{mol} \mathrm{ml}^{-1} \mathrm{~min}^{-1}$ ) respectively. The results of microbial protein synthesis and cellulolytic activity at each treatment were in normal level. The addition of the zeolite level as slow release nitrogen source up to $4 \%$ increase microbial protein synthesis.
\end{abstract}

Keywords : Zeolites, microbial protein synthesis and activity of cellulolytic

\section{PENDAHULUAN}

Sumbangan sumber protein terbesar untuk kebutuhan ternak ruminansia berasal dari protein mikroba yaitu \pm $60-80 \%$ selain juga bersumber dari pakan dan protein enzim. Ketersediaan amonia dalam rumen sangat mempengaruhi populasi mikroba rumen sehingga berpengaruh pula pada sintesis protein mikroba. Salah satu sumber amonia yaitu hasil hidrolisis urea yang dibutuhkan ternak ruminansia sebagai sumber non protein nitrogen (NPN). Kelemahan dari urea yaitu mempunyai sifat higroskopis atau cepat terhidrolisis menjadi amonia didalam rumen, sehingga sebagian besar amonia akan mudah diserap dan masuk dalam sistem peredaran darah. Hal tersebut bisa menyebabkan keracunan pada ternak sehingga terjadi penurunan konsumsi pakan, bahkan menyebabkan kematian (Kardaya dkk, 2009). Perlu adanya modifikasi untuk mengikat amonia dan kemudian dilepaskan kembali secara perlahan.

Pemberian urea harus diimbangi dengan sumber karbohidrat yang fer- 
mentabel untuk mendukung proses fermentasi didalam rumen (Puastuti, 2010). Penambahan karbohidrat dalam pakan akan meningkatkan aktivitas metabolisme mikroba, laju pertumbuhan mikroba dan laju degradasi substrat oleh mikroba rumen (Kurniawati, 2004). Penambahan zeolit teraktivasi mampu mengikat amonia hasil hidrolisis urea kemudian dilepaskan secara lambat.

Zeolit merupakan mineral yang terbentuk dari batuan sedimen, tersusun atas aluminium dan silikat. Zeolit akan berikatan dengan kation yang berasal dari golongan alkali dan alkali tanah melalui atom oksigen. Kation-kation tersebut mampu bergerak bebas untuk menggantikan kation lain sehingga zeolit mempunyai kemampuan sebagai penukar ion. Zeolit jenis klinoptilolit mempunyai kapasitas menyerap ion yang tinggi, sehingga dapat dimanfaatkan sebagai reservoir amonia. Proses pelepasan amonia yang cepat akan menjadi lambat setelah ada penambahan zeolit jenis klinoptilolit sehingga pemanfaatan amonia akan lebih efisien (Celik et al., 2011).

Penelitian ini bertujuan untuk mengetahui pengaruh penambahan level zeolit sebagai sumber nitrogen slow release pada glukosa murni terhadap sintesis protein mikroba dan aktivitas selulolitik. Penambahan level zeolit sebagai sumber nitrogen slow release diharapkan dapat mensinkronkan ketersediaan amonia dan sumber energi yang berasal dari glukosa murni untuk sintesis protein mikroba. Manfaat dari penelitian ini yaitu memberi informasi mengenai sintesis protein mikroba dan aktivitas selulolitik dari pemanfaatan zeolit sebagai sumber nitrogen slow release serta glukosa sebagai sumber energi.

\section{MATERI DAN METODE}

Penelitian ini dilaksanakan pada tanggal 22 Februari - 15 April 2016 di
Laboratorium Ilmu Nutrisi dan Pakan Fakultas Peternakan dan Pertanian serta di Laboratorium Biokimia Fakultas Sains dan Matematika Universitas Diponegoro, Semarang.

Materi yang digunakan yaitu serbuk zeolit (klinoptilolit) berukuran 40-60 mesh, urea, glukosa murni, cairan rumen sapi dari RPH Ungaran. Reagen yang digunakan yaitu Lowry B dan Lowry A, Carboxy Methyl Cellulose (CMC) 1\%, larutan bufer asetat dengan $\mathrm{pH}$ 5,5, larutan Tri Chloroacetic Acid (TCA) 1,5 M, larutan Dinitrosalicylic Acid (DNS), akuades dan larutan McDougall. Sedangkan alat yang digunakan yaitu timbangan analitik, kertas minyak, crucible porcelain, tanur, eksikator, oven, tabung fermentor, tutup tabung fermentor, gelas ukur, gelas beker, erlenmeyer, waterbath, sentrifus, tabung sentrifus, spatula, tabung reaksi, rak tabung reaksi, magnetic stirrer, vortex, pipet ukur, spektrofotometer digital serta spektrofotometer UV-Vis.

Metode yang digunakan dalam penelitian terdiri dari dua langkah yaitu aktivasi zeolit kemudian pengukuran sintesis protein mikroba dan aktivitas selulolitik.

\section{Aktivasi zeolit}

Aktivasi zeolit dilakukan dengan cara: zeolit berukuran 40-60 mesh ditanur pada suhu $300^{\circ} \mathrm{C}$ selama 4 jam. Zeolit yang sudah ditanur selanjutnya dicampur dengan urea dan air dengan perbandingan $2: 1: 1(\mathrm{w} / \mathrm{w} / \mathrm{v})$ kemudian diinkubasi selama 48 jam. Zeolit yang sudah diinkubasi (zeolit sumber nitrogen slow release) ditambahkan kedalam glukosa murni pada masingmasing perlakuan sebanyak 2\% (T1), 4\% (T2), 6\% (T3), 8\% (T4) dan 10\% (T5), kemudian dilakukan pengujian secara in vitro. 


\section{Sintesis protein mikroba}

Pengukuran sintesis protein mikroba dimulai dengan pengujian secara in vitro. Sampel diinkubasi pada suhu $39^{\circ} \mathrm{C}$ selama 3 jam. Sampel disentrifus dengan kecepatan $3.000 \mathrm{rpm}$ selama 15 menit untuk mendapatkan supernatan. Supernatan disentrifus kembali dengan kecepatan $8.000 \mathrm{rpm}$ pada suhu ruang selama 15 menit untuk mendapatkan endapan mikroba.

Sintesis protein mikroba diukur menggunakan metode Lowry (Plumer, 1971). Langkah-langkah yang dilakukan yaitu: sampel hasil sentrifus

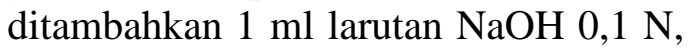
dihomogenkan. Sampel dimasukan ke tabung reaksi, dipanaskan pada suhu $90^{\circ} \mathrm{C}$ selama 15 menit kemudian didinginkan pada suhu ruang selama 10 menit. Sampel diambil $1 \mathrm{ml}$, ditambahkan $5 \mathrm{ml}$ larutan Lowry B kemudian divortex. Sampel didiamkan selama 10 menit pada suhu kamar. Selanjutnya ditambahkan larutan Lowry A $0,5 \mathrm{ml}$, divortex, didiamkan selama 30 menit. Sampel dibaca menggunakan spektrofotometer digital dengan panjang gelombang $700 \mathrm{~nm}$.

\section{Aktivitas selulolitik}

Pengukuran aktivitas enzim selulase dimulai dengan pengujian secara in vitro. Sampel diinkubasi pada suhu $39^{\circ} \mathrm{C}$ selama 3 jam. Sampel disentrifus dengan kecepatan $3.000 \mathrm{rpm}$ selama 15 menit untuk mendapatkan supernatan. Supernatan disentrifus kembali dengan kecepatan $8.000 \mathrm{rpm}$ pada suhu ruang selama 15 menit untuk mendapatkan filtrat sebagai uji aktivitas selulolitik.

Pengujian aktivitas selulolitik dilakukan dengan metode Patra (2006). Sebanyak 0,1 g CMC 1\% ditimbang, dimasukkan kedalam gelas beker kemudian dilarutkan kedalam $10 \mathrm{ml}$ bufer asetat pH 5,5. Sampel diambil seba- nyak $1 \mathrm{ml}$ dari pelarutan CMC, dimasukkan kedalam tabung reaksi kemudian ditambahkan 0,5 ml larutan enzim (filtrat hasil sentrifus) dan $0,5 \mathrm{ml}$ bufer asetat 0,05 $\mathrm{M} \mathrm{pH}$ 5,5. Sampel diinkubasi pada suhu $40^{\circ} \mathrm{C}$ selama 60 menit. Kemudian dilakukan pengukuran gula pereduksi dengan metode DNS yaitu hasil inkubasi ditambahkan 0,5 ml TCA 1,5 M dan $1 \mathrm{ml}$ larutan DNS, dilakukan penggojogan. Sampel dipanaskan pada air mendidih selama 10 menit kemudian didinginkan. Sampel ditambahkan dengan akuades hingga volume $10 \mathrm{ml}$. Pengukuran absorbansi pada sampel menggunakan spektrofotometer UV-Vis dengan panjang gelombang maksimum $470 \mathrm{~nm}$. 1 unit aktivitas selulase yaitu banyaknya enzim selulase yang dapat membentuk $1 \mu$ mol glukosa per menit pada kondisi optimum.

Rancangan penelitian yang digunakan yaitu rancangan acak lengkap (RAL) dengan 5 perlakuan dan 4 ulangan. Peubah yang diamati yaitu sintesis protein mikroba dan aktivitas selulolitik. Perlakuan yang diberikan antara lain :

T1 : Glukosa murni + tambahan level zeolit sumber nitrogen slow release $2 \%$

T2 : Glukosa murni + tambahan level zeolit sumber nitrogen slow release 4\%

T3 : Glukosa murni + tambahan level zeolit sumber nitrogen slow release 6\%

T4 : Glukosa murni + tambahan level zeolit sumber nitrogen slow release $8 \%$

T5 : Glukosa murni + tambahan level zeolit sumber nitrogen slow release $10 \%$

Model linier untuk penelitian sebagai berikut :

$$
\mathrm{Y}_{\mathrm{ij}}=\mu+\tau_{\mathrm{i}}+\varepsilon_{\mathrm{ij}}
$$

Keterangan :

$$
\mathrm{i} \quad=1,2,3,4,5 \ldots, \text { (perlakuan) }
$$


$\mathrm{j} \quad=1,2,3,4 \ldots$, (ulangan)

$\mathrm{i}, \mathrm{j}=1,2, \ldots ., \mathrm{n}$

Yij = Hasil sintesis protein mikroba dan aktivitas selulolitik dari perlakuan penambahan level zeolit sebagai sumber nitrogen slow release ke- i, dan ulangan ke- j.

$\mu \quad=$ Rataan umum

$\tau \mathrm{i}=$ Pengaruh perlakuan ke- $\mathrm{i}$

cij $=$ Galat percobaan perlakuan penambahan level zeolit sebagai sumber nitrogen slow release ke- i, ulangan ke- $\mathrm{j}$

Apabila perlakuan berpengaruh nyata $(\mathrm{P}<0,05)$ terhadap hasil percobaan maka dilanjutkan dengan uji wilayah ganda Duncan.

\section{HASIL DAN PEMBAHASAN}

Data hasil analisis sintesis protein mikroba dan aktivitas selulolitik akibat penambahan level zeolit disajikan pada Tabel 1.

Tabel 1. Rata-rata hasil analisis sintesis protein mikroba dan aktivitas selulolitik akibat penambahan level zeolit

\begin{tabular}{|c|c|c|c|c|c|}
\hline \multirow{2}{*}{ Parameter } & \multicolumn{4}{|c|}{ Perlakuan } & \\
\hline & $\mathrm{T} 1$ & $\mathrm{~T} 2$ & T3 & $\mathrm{T} 4$ & T5 \\
\hline Sintesis protein mikroba $(\mathrm{mg} / \mathrm{ml})$ & $31,68^{d}$ & $59,50^{\mathrm{a}}$ & $55,58^{\mathrm{ab}}$ & $47,55^{\mathrm{bc}}$ & $42,82^{\text {cd }}$ \\
\hline Aktivitas selulolitik $\left(\mu \mathrm{mol} \mathrm{ml} \mathrm{m}^{-1}\right.$ menit $\left.^{-1}\right)$ & $2,09^{\mathrm{b}}$ & $2,23^{\mathrm{b}}$ & $2,16^{\mathrm{b}}$ & $2,36^{\mathrm{b}}$ & $3,55^{\mathrm{a}}$ \\
\hline
\end{tabular}

Keterangan : Superskrip yang berbeda pada kolom yang sama menunjukkan adanya perbedaan nyata $(\mathrm{P}<0,05)$

\section{Sintesis protein mikroba}

Hasil analisis ragam menunjukkan bahwa perlakuan penambahan level zeolit sumber nitrogen slow release berpengaruh nyata $(\mathrm{P}<0,05)$ terhadap sintesis protein mikroba. Zeolit mampu berperan sebagai sumber nitrogen dalam sintesis protein mikroba karena sebelumnya telah mengikat amonia hasil hidrolisis urea dengan sumber energi berasal dari glukosa murni.

Tabel 1 menunjukkan bahwa sintesis protein terbanyak terdapat pada perlakuan T2 (59,50 mg/ml), diikuti oleh T3 $(55,58 \mathrm{mg} / \mathrm{ml}), \quad$ T4 $(47,55$ $\mathrm{mg} / \mathrm{ml}), \mathrm{T} 5(42,82 \mathrm{mg} / \mathrm{ml})$ dan sintesis protein terendah terdapat pada perlakuan $\mathrm{T} 1(31,68 \mathrm{mg} / \mathrm{ml})$. Sintesis protein mikroba hasil penelitian berkisar antara 31,68-59,50 $\mathrm{mg} / \mathrm{ml}$ dengan rata-rata sebesar 47,42 $\mathrm{mg} / \mathrm{ml}$. Perbedaan dari masing-masing perlakuan tersebut masih dalam taraf normal. Menurut Suryapratama and Suhartati (2012), sin- tesis protein mikroba yang mendapat tambahan minyak kedelai 0\% dan 3\% dalam ransum masing-masing yaitu 44,31 mg/ml dan 56,95 mg/ml. Perlakuan berupa ransum basal dengan tambahan dedak padi, onggok basah dan kering serta jagung menghasilkan sintesis protein mikroba yang seragam yaitu $\pm 68,21-72,93 \mathrm{mg} / \mathrm{ml}$. Beberapa sumber karbohidrat tersebut termasuk kelompok karbohidrat fermentable yang akan mudah dicerna oleh mikroba rumen (Hindratiningrum dkk. 2011).

Sintesis protein mikroba yang optimal membutuhkan suplai nitrogen dan asam organik. Suplai nitrogen berasal dari produksi amonia, sedangkan asam organik akan terpenuhi dari produksi VFA yang merupakan hasil fermentasi karbohidrat. Rendahnya konsentrasi amonia mengindikasikan bahwa lebih banyak sumber nitrogen yang dimanfaatkan mikroba untuk mensintesis sel tubuhnya. Kurniawati (2004) 
menyatakan bahwa penambahan karbohidrat dalam pakan akan meningkatkan aktivitas metabolisme mikroba, laju pertumbuhan mikroba dan laju degradasi substrat oleh mikroba rumen.

Banyaknya sintesis protein mikroba rumen didukung oleh adanya sumber nitrogen yang berasal dari zeolit, dimana sebelumnya zeolit telah mengikat amonia hasil hidrolisis urea. Zeolit dengan cepat akan menukar ion $\mathrm{NH}_{4}{ }^{+}$yang berasal dari senyawa NPN dan mengikatnya kemudian akan dilepaskan oleh ion $\mathrm{Na}^{+}$saliva yang masuk kedalam rumen (Migliorati et al., 2007). Sintesis protein mikroba bergantung pula pada ketersediaan karbohidrat. Karbohidrat sederhana berupa glukosa menjadi sumber energi utama serta sebagai kerangka karbon untuk proses sintesis protein tubuhnya. Menurut Murtidjo (1990), populasi mikroba rumen akan meningkat ketika ketersediaan nutrien memenuhi kebutuhan mikroba sehingga akan meningkatkan sintesis protein. Sintesis protein membutuhkan non protein nitrogen dan sumber karbohidrat dari pakan.

Keseimbangan dalam degradasi senyawa nitrogen dan sumber energi sangat mempengaruhi hasil sintesis protein mikroba. Hal ini sesuai dengan pendapat Pathak (2008) bahwa faktor yang mempengaruhi sintesis protein mikroba adalah konsumsi bahan kering, suplai senyawa nitrogen, suplai energi terfermentasi, rasio hijauan dengan konsentrat pada ransum, sinkronisasi nitrogen dan energi, lingkungan rumen, laju makanan, vitamin dan mineral.

Ternak ruminansia memperoleh asupan sumber protein terbesar berasal dari protein mikroba yaitu sekitar 60$80 \%$, sisanya berasal dari protein pakan dan protein enzim. Jumlah mikroba didalam rumen akan mempengaruhi banyaknya sintesis protein mikroba. Jenis mikroba rumen menurut Russel et al. (1992) terbagi menjadi dua yaitu mikroba yang menggunakan karbohidrat struktural dan mikroba yang menggunakan karbohidrat non struktural. Menurut Ismartoyo (2011), beberapa spesies mikroba rumen mampu menghasilkan enzim selulase yang berguna sebagai pendegradasi isi sel dan dinding sel tanaman. Degradasi pakan oleh ternak ruminansia dilakukan didalam rumen dan sebagian besar kebutuhan ternak berasal dari hasil degradasi sel tanaman.

\section{Aktivitas selulolitik}

Berdasarkan analisis ragam terdapat pengaruh nyata $(\mathrm{P}<0,05)$ aktivitas selulolitik akibat penambahan level zeolit sumber nitrogen slow release (Tabel 1). Aktivitas selulolitik terbesar terdapat pada perlakuan T5 $\left(3,55 \mu \mathrm{mol} \mathrm{ml} \mathrm{m}^{-1}\right.$ menit $\left.{ }^{-1}\right)$, disusul oleh T4 $\left(2,36 \mu \mathrm{mol} \mathrm{ml}^{-}\right.$ ${ }^{1}$ menit $\left.^{-1}\right)$, T2 $\left(2,23 \mu \mathrm{mol} \mathrm{ml}^{-1}\right.$ menit $\left.^{-1}\right)$, T3 $\left(2,16 \mu \mathrm{mol} \mathrm{ml}^{-1}\right.$ menit $\left.^{-1}\right)$ dan aktivitas selulolitik terendah terdapat pada perlakuan T1 (2,09 $\mu \mathrm{mol} \mathrm{ml}{ }^{-1}$ menit $\left.{ }^{-1}\right)$. Hasil analisis aktivitas selulolitik akibat penambahan level zeolit sumber nitrogen slow release berkisar antara 2,093,55 $\mu \mathrm{mol} \mathrm{ml}{ }^{-1}$ menit $^{-1}$ dengan rata-rata sebesar 2,48 $\mu \mathrm{mol} \mathrm{ml}^{-1}$ menit $^{-1}$. Hasil tersebut lebih rendah dari penelitian Moharrery and Das (2001) bahwa aktivitas selulolitik dari cell free rumen fluid sebesar 2,70-4,15 $\mu \mathrm{mol} \mathrm{ml}{ }^{-1}$ menit $^{-1}$.

Aktivitas selulolitik sangat bergantung pada jenis dan jumlah substrat berupa serat. Apabila kandungan serat pakan tinggi maka tingkat aktivitas enzim selulase naik. Tingginya aktivitas selulolitik disebabkan oleh kemampuan mikroba yang mencerna selulosa secara cepat. Menurut Jouany (1991), kecepatan degradasi oleh mikroba rumen tergantung pada jenis selulosa. Jenis kristal dapat memperlambat degradasi 
pakan sehingga aktivitas mikroba dan aktivitas enzim menurun.

Satu unit aktivitas selulase diartikan sebagai banyaknya enzim selulase yang dapat membentuk $1 \mu \mathrm{mol}$ glukosa per menit pada kondisi optimum. Besar kecilnya nilai aktivitas enzim mempengaruhi kadar gula pereduksi yang dihasilkan selama aktivitas berlangsung. Menurut Rahmi dkk. (2013), glukosa merupakan kelompok gula sederhana yang secara langsung dapat digunakan bakteri rumen tanpa didegradasi terlebih dahulu dalam proses metabolismenya. Akibatnya pembelahan sel terjadi secara cepat dan jumlah sel bertambah banyak sehingga konsentrasi enzim dan aktivitas enzim akan semakin besar.

Kerja mikroba mempengaruhi aktivitas enzim, ketika aktivitas mikroba rumen terganggu maka aktivitas enzim akan terganggu. Banyaknya penambahan karbohidrat pada perlakuan akan meningkatkan aktivitas selulolitik. Menurut McDonald et al. (2002), aktivitas enzim dipengaruhi oleh konsentrasi substrat, konsentrasi enzim, inhibitor, dan faktor lingkungan (suhu dan $\mathrm{pH}$ ).

\section{KESIMPULAN}

Berdasarkan hasil penelitian dapat disimpulkan bahwa penambahan level zeolit sumber nitrogen slow release tidak mengganggu metabolisme mikroba rumen. Sintesis protein dan aktivitas selulolitik yang dihasilkan pada masing-masing perlakuan masih dalam taraf normal. Penambahan level zeolit sumber nitrogen slow release hingga taraf $4 \%$ meningkatkan sintesis protein mikroba.

\section{DAFTAR PUSTAKA}

Celik, M. S., B. Ozdemir, M. Turan, I. Koyuncu, G. Atesok dan H. Z. Sarikaya. 2011. Removal of ammonia by natural clay minerals us- ing fixed and fluidised bed column reactors. Water Sci. and Technol. Water Supply. 1 (1): 81 -88 .

Hindratiningrum, N., M. Bata dan S. A. Santosa. 2011. Produk fermentasi rumen dan produksi protein mikroba sapi lokal yang diberi pakan jerami amoniasi dan beberapa bahan pakan sumber energy. Agripet. 11 (2) : 29 - 34 .

Ismartoyo. 2011. Pengantar teknik penelitian degradasi pakan ternak ruminansia. Brilian Internasional, Surabaya.

Jouany, J. P. 1991. Defaunation of the rumen. In: J.P Jouany (Ed.). Rumen microbial metabolism and ruminant digestion. INRA, Paris.

Kardaya, D., K. G. Wiryawan, A. Parakkasi dan H. M. Winugroho. 2009. Karakteristik urea lepas lamban pada berbagai kadar molases dalam ransum berbasis jerami padi secara in vitro. J. Ilmu Ternak dan Veteriner. 14 (3) : 177 - 191.

Kurniawati, A. 2004. Pertumbuhan mikroba rumen dan efisiensi pemanfaatan nitrogen pada silase Red Clover (Trifolium pratense $\mathrm{cv}$. Sabatron). Pusat Penelitian dan Pengembangan Teknologi Isotop dan Radiasi. BATAN, Jakarta (Risalah Seminar Ilmiah Penelitian dan Pengembangan Aplikasi Isotop dan Radiasi).

McDonald P., R. A. Edwards, J. F. D Greenhalgh dan C. A. Morgan. 2002. Animal nutrition. $6^{\text {th }}$ Ed. Prentice Hall Publishing, New Jersey.

Migliorati, L., F. Abeni, M. P. Cattaneo, C. Tornielli dan G. Pirlo. 2007. Effects of adsorbent in dairy cow diet on milk quality and cheesemaking properties. Italian J. Anim. Sci. 6 (1): 460 - 462. 
Moharrery, A. and T. K. Das. 2001. Correlation between microbial enzyme activities in the rumen fluid of sheep under different treatments. Reprod. Nutr. Dev. 41 : $513-529$.

Murtidjo, B. A. 1990. Sapi potong. Kanisius, Yogyakarta.

Pathak, A. K. 2008. Various factors affecting microbial protein synthesis in the rumen. Vet. World. 1 (6) : $186-189$.

Patra, A. K. 2006. Effect of plant extracts on in vitro methanogenesis, enzyme activites and fermentation of feed in rumen liquor of buffallo. Anim. Feed Sci. Technol. $128: 276$ - 291.

Plummer, D. T. 1971. An introduction to practical biochemistry. McGraw-Hill Publ., London.

Puastuti, W. 2010. Urea dalam pakan dan implikasinya dalam fermentasi rumen kerbau. Seminar dan
Lokakarya Nasional Kerbau, Bogor. Hal. : 89 - 94.

Rahmi, F. L., A. Dahliaty dan S. Devi. 2013. Optimalisasi komposisi media dan konsentrasi sumber karbon produksi enzim selulase bakteri selulolitik strain lokal S16 dan S-22. Fakultas Matematika dan Ilmu Pengetahuan Alam Universitas Riau, Pekanbaru (Karya Ilmiah).

Russel, J. B., J. D. O'connors, D. G. Fox, P. J. Van Soest dan C. J. Sniffen. 1992. A net carbohydrate and protein system for evaluating cattle diets : l. Ruminal fermentation. J. Anim. Sci. 70 (11) : 3551 3561.

Suryapratama W. and F. M. Suhartati. 2012. Increasing rumen microbial protein synthesis with additional dietary substrate of Saccharomyces cerevisiae and soybean oil. Anim. Product. 14 (3) : 155-159. 